\title{
Afrikaans en interdissiplinêre studie: moontlikhede en eise in 'n toekomstige Suid-Afrika
}

\begin{abstract}
The main aim of this article is to try to provide further grounds for the argument that Afrikaans cannot be ignored in a future South Africa. Reasons substantiating this claim are inter alia the following: Afrikaans is generally recognized as the langwage with the largest number of speakers in South Africa; it succeeds in fulfilling both its high and low functions in the South African community; it has validity as a language of science (although much still needs to be done in this regard) and it plays an important role in an inter-disciplinary approach to research and the gaining of knowledge in various fields.
\end{abstract}

\section{Inleiding}

Die titel van hierdie artikel leen hom tot 'n hele aantal moontlike besprekingspunte, onder meer

- wat is interdissiplinêre studie?

- $\quad$ kán dissiplines mekaar beïnvloed?

- Afrikaans en sy rol in 'n 'Nuwe Suid-Afrika'

- hét Afrikaans 'n rol te speel in interdissiplinêre studies?

- gaan Afrikaans in die toekoms (hoegenaand) ter sake wees vir die aanbied van ander dissiplines?

1 Hicrdic artikel is ' $n$ verwerking van 'n referaat wat gelewer is tydens dic recks Stokerlesings wat in Augustus 1992 deur die Dept. Filosofic van dic PU vir CHO op dic kampus van dic $\mathrm{PU}$ vir $\mathrm{CHO}$ angebied is 
Dit is onmoontlik om in die bestek van ' $n$ artikel soos hierdie enigsins ' $n$ samehangende beeld van die bogenoemde (en selfs moontlike ander) aspekte te gee. Daarom sal daar eerder probeer word om ter wille van die ontwikkeling van die argument te konsentreer op die onderstaande relevante aspekte:

- as agtergrond: Afrikaans en sy posisie (getalle, status, funksies) in SuidAfrika as taal onder tale;

- die gebruik van Afrikaans in die beoefening van die wetenskap in SuidAfrika; en

- Afrikaans as vakdissipline en sy waarde vir die beoefening van ander vakdissiplines.

Elkeen van hierdie aspekte sal op sigself ' $n$ artikel kan vorm, maar hier word dit net kortliks aangeraak om 'n bepaalde punt tuis te bring, naamlik dat Afrikaans (en ook die vak Afrikaans/Afrikaans en Nederlands) beslis 'n rol te speel sal hê in 'n 'nuwe Suid-Afrika'.

\section{Afrikaans as taal onder tale in Suid-Afrika}

Die feite en argumente wat in hierdie verband aangevoer kan word, is redelik bekende gegewens wat die afgelope paar jaar al in verskeie wetenskaplike en populêre publikasies onder die aandag van belangstellendes gebring is. ${ }^{2}$

\subsection{Afrikaans en sy aantal sprekers}

Statistiek oor Afrikaans as moedertaal, as tweedetaal, as ekonomies-noodsaaklike taal (soos Odendal [1992:22] sê: "brood- en botter-taalsprekers") is geredelik beskikbaar. ${ }^{3}$ Hoeveel 'n mens kan aflei uit dergelike statistiek oor hoeveel SuidAfrikaners Afrikaans op die een of ander manier magtig is, is weer ' $n$ ander vraag, want soos Combrink (1992:10) sê: "Getalle verskil na gelang van wat die navor-

2 Vgl. hicroor o.m. Du Plessis \& Du Plessis (reds.), 1987; Du Plessis, 1992; Grobler c.a., 1990; Prinsloo \& Van Rensburg (reds.). 1984; Prinsloo \& Malan, 1988; Prinsloo, 1985; Webb (red.), 1992. Verskeic artikels in kocrante en tydskriftc (soos Huisgenoot, Sarie, Rooi Rose, De Kat, Insig, Die Suid-Afrikaan, c.a) het ook al oor hierdie (en verwante) aspek(te) verskyn. Etlike radioprogramme is ook reeds hicraan gewy - publikasies soos onder meer Carstens \& Waher (reds.), 1990 en Carstens (red.), 1993 het as gevolg hiervan verskyn.

3 Raadpleeg in hierdic verband veral Du Plessis, 1992:48; Grobler c.a., 1990; Prinsloo, 1985:30; Prinsloo \& Malan, 1988:281. Bruikbare inligting word verder verskaf in die ATKV-pamflet van 1991 ("13.3 miljoen redes om Afrikaans tc praat") asook Nuusbrief Vier (1992) van die Ad hoc-Komitec oor dic Onderrig van Afrikaans 
sers as databasis gebruik, en na gelang van wat die doel met die vraag en antwoord is."

As vertrekpunt kan die gegewens uit die bekende tabelverwerkte statistiek van die 1980-sensus (vergelyk Prinsloo, 1985:30, Prinsloo \& Malan, 1988:281) weergegee word. Die tabel wat aangegee word in Prinsloo \& Malan (1988:281), word hier onder afgedruk:

Tabel 1: Sensusgegewens (1980) oor huistaal in die RSA (gebaseer op 'n 5 persent steekproef van die totale bevolking)

\begin{tabular}{|c|c|c|c|c|c|c|}
\hline \multicolumn{2}{|r|}{ Taal } & Blankes & Kleurlinge & Indiërs & Swartes & Totaal \\
\hline \multirow[t]{2}{*}{1.} & \multirow[t]{2}{*}{$\begin{array}{l}\text { Amptelike Tale } \\
\text { Afrikaans } \\
\text { Engels }\end{array}$} & \multirow[t]{2}{*}{$\begin{array}{l}2581080 \\
1763220\end{array}$} & \multirow[t]{2}{*}{$\begin{array}{r}2251860 \\
324360\end{array}$} & \multirow[t]{2}{*}{$\begin{array}{r}15500 \\
698940\end{array}$} & \multirow[t]{2}{*}{$\begin{array}{l}77320 \\
29120\end{array}$} & $\begin{array}{l}4925760 \\
2815640\end{array}$ \\
\hline & & & & & & 7741400 \\
\hline \multirow[t]{2}{*}{2.} & \multirow[t]{2}{*}{$\begin{array}{l}\text { Ander Europese tale } \\
\text { Nederlands } \\
\text { Duits } \\
\text { Grieks } \\
\text { Italiaans } \\
\text { Portugees } \\
\text { Frans }\end{array}$} & \multirow[t]{2}{*}{$\begin{array}{r}11740 \\
40240 \\
16780 \\
16600 \\
57080 \\
6340\end{array}$} & \multirow[t]{2}{*}{$\begin{array}{l}- \\
\overline{-} \\
\overline{-} \\
\overline{-} \\
-\end{array}$} & \multirow[t]{2}{*}{$\begin{array}{l}- \\
- \\
- \\
- \\
-\end{array}$} & \multirow[t]{2}{*}{$\begin{array}{l}- \\
- \\
- \\
- \\
-\end{array}$} & $\begin{array}{r}11740 \\
40240 \\
16780 \\
16600 \\
57080 \\
6340\end{array}$ \\
\hline & & & & & & 148780 \\
\hline \multirow[t]{2}{*}{3.} & \multirow[t]{2}{*}{$\begin{array}{l}\text { Oosterse Tale } \\
\text { Tamil } \\
\text { Hindi } \\
\text { Telegu } \\
\text { Goedsjarati } \\
\text { Urdu } \\
\text { Chinees }\end{array}$} & \multirow[t]{2}{*}{$\begin{array}{l}- \\
- \\
- \\
- \\
- \\
-\end{array}$} & \multirow[t]{2}{*}{$\begin{array}{l}- \\
- \\
- \\
- \\
-\end{array}$} & \multirow[t]{2}{*}{$\begin{array}{r}24720 \\
25900 \\
4000 \\
25120 \\
13280 \\
2700\end{array}$} & \multirow[t]{2}{*}{$\begin{array}{l}- \\
- \\
- \\
- \\
- \\
-\end{array}$} & $\begin{array}{rl}24 & 720 \\
25 & 900 \\
4000 \\
25 & 120 \\
13 & 280 \\
2700\end{array}$ \\
\hline & & & & & & 95720 \\
\hline \multicolumn{2}{|l|}{4.} & \multicolumn{5}{|c|}{ Afrikatale - groottotaal 16777322} \\
\hline \multirow[t]{2}{*}{4.1} & \multirow[t]{2}{*}{$\begin{array}{l}\text { Nguni-tale } \\
\text { Xhosa } \\
\text { Zoeloe } \\
\text { Swazi } \\
\text { Suid-Ndebele } \\
\text { Noord-Ndebele }\end{array}$} & \multirow[t]{2}{*}{$\begin{array}{l}- \\
\text { - } \\
- \\
-\end{array}$} & \multirow[t]{2}{*}{$\begin{array}{r}8440 \\
5580 \\
1060 \\
440 \\
100\end{array}$} & \multirow[t]{2}{*}{$\begin{array}{l}- \\
\overline{-} \\
\overline{-} \\
\overline{-}\end{array}$} & \multirow[t]{2}{*}{$\begin{array}{r}2870920 \\
6058900 \\
649540 \\
289220 \\
170120\end{array}$} & $\begin{array}{r}2879360 \\
6064480 \\
650600 \\
289660 \\
170220\end{array}$ \\
\hline & & & & & & 10054322 \\
\hline \multirow[t]{2}{*}{4.2} & \multirow[t]{2}{*}{$\begin{array}{l}\text { Sotho/Tswana } \\
\text { Noord-Sotho } \\
\text { Suid-Sotho } \\
\text { Tswana }\end{array}$} & \multirow[t]{2}{*}{ - } & \multirow[t]{2}{*}{$\begin{array}{l}2440 \\
5320 \\
9300\end{array}$} & \multirow[t]{2}{*}{$\begin{array}{l}- \\
-\end{array}$} & \multirow[t]{2}{*}{$\begin{array}{l}2429180 \\
1872520 \\
1346360\end{array}$} & $\begin{array}{l}2431620 \\
1877840 \\
1355660\end{array}$ \\
\hline & & & & & & 5665120 \\
\hline 4.3 & Tsonga & - & 1180 & - & 886960 & 888140 \\
\hline 4.4 & Venda & - & 40 & - & 169700 & 169740 \\
\hline & Ander & 35020 & 2660 & 11160 & 73900 & 122740 \\
\hline & Totaal & 4528100 & 2612780 & 821320 & 16923760 & 24886020 \\
\hline
\end{tabular}


Die gegewens/statistiek wat in dié tabel weergegee is, sluit die sogenaamde TBVC-state 4 uit. In die lig van die totale tale-opset in Suid-Afrika word hier eerder gewerk met die statistiek wat ook hierdie state insluit en daarom sal daar noodwendig 'n verskil wees tussen die syfers wat in Tabel 1 opgeneem is en dit wat in die volgende paragraaf verstrek word.

Volgens Tabel 1 is Afrikaans een van 24 (Europese, Oosterse en Afrika-) tale wat in Suid-Afrika gepraat word, maar het dit in terme van die totale spreker-getalle ' $n$ voorsprong bó sommige van die ander tale. Uit $\pm 30,5$ miljoen sprekers (dit is nou mét insluiting van die TBVC-state) word Afrikaans deur \pm 5 miljoen as huis/moedertaal gebruik - dit is $16,20 \%$ van die totale bevolking - Engels deur $9,07 \%$, Xhosa deur $18,04 \%$ en Zoeloe deur $21,4 \%$. Afrikaans was dus in 1980 die derde grootste huistaal naas Zoeloe en Xhosa. Afrikaans was egter die taal met die grootste totale aantal sprekers (dit is moedertaal-, tweedetaalsprekers en andersins), naamlik 43,6\% van die hele bevolking, oftewel 13,3 miljoen mense vergelyk in hierdie verband die pamflet wat in 1991 deur die ATKV (met die hulp van die RGN) uitgegee is onder die titel " 13.3 miljoen redes om Afrikaans te praat". Die ooreenstemmende syfers vir Engels was $40,5 \%$ (dit wil sê 12,3 miljoen sprekers). Daarenteen kon $44 \%$ van die totale bevolking 'n Nguni-taal ${ }^{\text {s }}$ (Zoeloe, Xhosa, Swati, Ndebele) as huistaal praat en $24 \%$ 'n Sotho-taal.

Hierdie prentjie het volgens ander bronne sedertdien ietwat verander (vergelyk LiCCA 1991; Nuusbrief Vier (1992) van die Ad hoc-Komitee oor die Vernuwing van die Onderrig van Afrikaans; Du Plessis, 1992:48). Vergelyk in hierdie verband ook Tabel 2 wat aangegee is in Nuusbrief Vier (1992:2) van die Ad hocKomitee oor die Onderrig van Afrikaans:

4 Die sogenaamde TBVC-state is die volgende: Transkei, Bophuthatswana, Venda en Ciskei. Aangesien dié state onder die vroeëre politicke bedeling as 'onafhanklik' beskou is, is hulle statistick nie verreken in die 1980-sensus as behorende tot die bevolking van SuidAfrika nie.

5 Daar kan hier miskien geargumenteer word dat meer mense uit die totale Suid-Afrikaanse bevolking 'n Nguni-taal kan verstaan (44\%) as wat die geval is met Afrikaans $(43,6 \%)$. Dis egter belangrik om in ag te necm dat dic Nguni-taalgroep vier talc insluit, naamlik Zocloc, Xhosa, Swati en Ndebele, teenoor Afrikaans as enkele taal. Dic vergelyking in die aangehaalde statistiek berus daarom eerder op die syfers vir een taal (bv. Afrikaans as lid van die Germaanse taalgroep) in teenstelling met dié van ' $n$ ander taal (bv. Zocloe as lid van die Nguni-taalgroep). 
Tabel 2:

Suid-Afrikaanse huistale: Getal en persentasie van SA bevolking, 1946 tot 2000 (Bron: RGN)

\begin{tabular}{|c|c|c|c|c|c|c|c|c|c|c|}
\hline \multirow{2}{*}{$\begin{array}{l}\text { Sensus } \\
\text { Jaar }\end{array}$} & \multicolumn{2}{|c|}{ Afrikaans } & \multicolumn{2}{|l|}{ Engels } & \multicolumn{2}{|l|}{ Afrikatale } & \multicolumn{2}{|l|}{ Ander } & \multicolumn{2}{|l|}{ Totaal } \\
\hline & Getal & $\%$ & Getal & $\%$ & Getal & $\%$ & Getal & $\%$ & Getal & $\%$ \\
\hline 1946 & 2415521 & 19,40 & 1067988 & 8,58 & 8296329 & 66,63 & 670943 & 5,39 & 12450781 & 100,00 \\
\hline 1951 & 2700156 & 19,28 & 1209249 & 8,63 & 9474351 & 67,64 & 624298 & 4,46 & 14008054 & 100,00 \\
\hline 1960 & 3370976 & 18,83 & 1432548 & 8,00 & 12382515 & 69,15 & 719825 & 4,02 & 17905865 & 100,00 \\
\hline 1970 & 4193017 & 17,82 & 1910493 & 8,12 & 16186079 & 68,80 & 1237069 & 5,26 & 23526658 & 100,00 \\
\hline 1980 & 4939704 & 16,20 & 2765541 & 9,07 & 22136257 & 72,6 & 650698 & 2,13 & 30492200 & 100,00 \\
\hline 1990 & 6188981 & 15,66 & 3432042 & 8,68 & 28962280 & 73,27 & 942697 & 2,39 & 39526000 & 100,00 \\
\hline 2000 & 7575342 & 14,73 & 4501394 & 8,75 & 38453137 & 74,78 & 891126 & 1,73 & 51421000 & 100,00 \\
\hline
\end{tabular}

Hieruit kan afgelei word dat Afrikaans se posisie die afgelope tien jaar ietwat verander het: van 4,9 miljoen (16,20\%) moedertaalsprekers in 1980 tot 6,2 miljoen $(15,66 \%)$ in 1990 - dus getalsgewys meer sprekers, maar persentasiegewys ' $n$ kleiner deel van die totale bevolking ( 39,5 miljoen). Geprojekteer na die jaar 2000 sal die dalende tendens (14,73\%, 7,6 miljoen) voortgesit word. Die ooreenstemmende syfers vir Engels en die Afrikatale kan ook in Tabel 2 verkry word. Die LiCCA-syfers (1991:14) dui aan dat Afrikaans egter steeds die derde grootste huistaalsprekerskorps in Suid-Afrika het, naamlik $15,66 \%$ teenoor Zoeloe se $21,61 \%$ en Xhosa se $17,44 \%$.

Hiennee is probeer om ' $n$ kort oorsig te gee van die statistiek rondom die getalleposisie van Afrikaans in Suid-Afrika as ' $n$ taal onder (ander) tale: Afrikaans is binne die talespektrum van Suid-Afrika dus 'n taal waarmee deeglik rekening gehou moet word, want dis nie net die derde grootste moedertaal in die land nie, maar dit kan ook daarop aanspraak maak "... dat hy deur meer mense verstaan en gepraat word as enige ander enkele Suid-Afrikaanse taal" (Du Plessis, 1992:31).

\subsection{Afrikaans en sy funksies}

Dat Afrikaans stewig gevestig is as sowel hoë- as laefunksietaal, staan vas. Du Plessis (1992:31) sê dat Afrikaans bewys kan lewer van sy prestasies as (hoëfunksie-)taal van die akademie, onderwys, godsdiens, letterkunde, regspleging, regering en tot in 'n sekere mate as taal van die ekonomie. 
Ook as laefunksietaal (dus as algemene omgangstaal, die spreektaal van die 'gewone man') is Afrikaans se posisie stewig: hy word algemeen en spontaan gebruik as dié middel van kommunikasie rondom braaivleisvure, in die loopgange van winkelsentrums in dorpe en stede, in teaters en bioskope, langs sportvelde, in busse en treine, langs strande, in die werksplek, in klaskamers (van skole, kolleges, technikons, universiteite), in huise rondom die etenstafel, voor die televisie, en so meer.

Dat politiek Afrikaans egter ook seergemaak het, en selfs sommige van sy funksies nadelig geaffekteer het, word redelik algemeen in die relevante literatuur aanvaar. In 'n referaat by die (Junie) 1992-jaarvergadering van die S.A. Akademie vir Wetenskap en Kuns op Potchefstroom het prof. Johan Combrink (voorsitter van die Taalkommissie) byvoorbeeld gewys op die negatiewe simboliese waarde van Afrikaans, naamlik dat dit deur baie mense beskou word as dié taal waarin ' $n$ verdrukkende politieke bestel aan hulle opgedwing is. Al het Van Rensburg (1989) reeds aangetoon dat Afrikaans as taal onregverdiglik die skuld dra vir die onreg wat deur sommige van (en nie al) die sprekers van Afrikaans gepleeg is, moet aanvaar word dat daar hard gewerk sal moet word om Afrikaans in die toekoms sy regmatige simboliese plek as taal onder (ander Afrika-)tale te laat inneem. Dit is sake wat nie in 'n oogwink kan gebeur nie, maar dit sal die eindresultaat wees van (a) ' $n$ lang oorredingsproses dat Afrikaans en sy sprekers ook iets goeds by te dra het tot die toekomstige ontwikkeling van hierdie land en (b) 'n positiewe gesindheidsverandering onder Afrikaanssprekendes oor hulle taal se funksionaliteit as taal óók van die toekoms in Suid-Afrika. (Vergelyk Combrink, 1991, 1992:6-10.)

\section{Kennis van Afrikaans en die beoefening van die wetenskap in Suid-Afrika}

\subsection{Die waarde van Afrikaans}

In sy bekende boek Tuiste in eie taal. Die behoud en bestaan van Afrikaans (1980) sê Jaap Steyn: "Die Afrikaanssprekende moet die posisie van Afrikaans versterk deur bewys van sy waarde te lewer" (p. 426). Hierdie uitspraak is gelewer ná 'n oorsigtelike bespreking (vergelyk Steyn, 1980:326-327, 420-422), waarin hy eintlik sy pessimisme laat blyk oor die gebruik van Afrikaans as wetenskapstaal in Suid-Afrika. Hy haal Heinz Kloss aan wat dit het oor die argument $" .$. dat ' $n$ mens in 'n moderne kultuurtaal oor al die belangrike vrae van die Westerse kultuur, nywerheid en tegnologie moet kan praat en skryf". Hy sê verder ook (Steyn, 1980:420) dis 'n "... onomstootlike feit dat 'n taal se waarde as kultuurtaal gemeet word aan sy vermoë om vir die natuurwetenskappe en tegnologie gebruik te word". 
Die vraag is nou inderdaad: hoe vaar Afrikaans in hierdie verband? Kan (en word) Afrikaans ook gebruik vir die uitdra van kennis in die beoefening van sy wetenskap, vir die bekendmaking van navorsingsresultate oor aspekte van die wetenskap? Steyn (1980:421) haal hieroor onder meer die siening van F.I.J. van Rensburg aan wat sê dat 'n lewenskragtige letterkunde nie 'n genoegsame waarborg of motivering is om aan ' $n$ taal ' $n$ voortbestaansrede te gee nie. Eers as Afrikaans kan toon dat hy óók kan antwoord op eise soos: 'Waar is jou Afrikaanse wysbegeerte?' 'Jou Afrikaanse teologie?' 'Jou Afrikaanse chemie?' "... sal hy kan bewys dat hy spektrum het, en gevolglik volwaardigheid".

\subsection{Die 'gebruik' van Afrikaans as wetenskapstaal}

Volgens Steyn (1980:421) tel dit sterk in Afrikaans se guns dat dit voertaal/ onderrigtaal aan 'n paar universiteite is, en gevolglik voortdurend as wetenskapstaal gebruik word. Dit alleen is egter nie genoeg om aan Afrikaans die status van 'n volwaardige wetenskapstaal te gee nie - prof. J. du P. Scholtz (1969-soos aangehaal deur Steyn 1980:325-326) sê hieroor:

Die waarde van 'n kultuurtaal word bereken, feitlik uitsluitlik bereken, op grond van wat van blywende waarde in boek en tydskrifartikel verskyn ... Waar is, byvoorbeeld, ons groot werke (in Engels verskyn hulle wel) oor ons boukuns, Kaapse meubels en silwer, oor ons diere, voëls en visse, oor ons bome, plante en blomme?

Sedert hierdie opmerking gemaak is in 1969 (24 jaar gelede), het daar al heelwat gebeur en het die posisie baie (indien nie drasties nie) verbeter, want talle populêre boeke van formaat hét al in Afrikaans verskyn. Daar is onder meer boeke oor belangrike politieke en militêre gebeurtenisse, oor Kaapse meubels, oor diere, voëls en visse, oor bome, plante en blomme, en so meer, maar die vraag is nog steeds: waar is daardie gróót werk, daardie werk wat Suid-Afrika (en Afrikaans) op die wêreldkaart sal plaas?

\subsection{Wetenskapsinsette: vakartikels en handboeke}

'n Belangrike eienskap van 'n wetenskapstaal (en daarmee saam die verdere uitbouing van die hoë funksies van die taal) is die skryf van handboeke en vakartikels deur wetenskaplikes, want dit is deur hierdie soort bronne dat die verworwe kennis vir die volgende geslagte in hulle eie taal toeganklik gemaak word. Hoe het Afrikaans in hierdie opsig gevaar? 
Hierdie vraag kan in 'n mate wel toegelig word met behulp van Garbers (1990) se artikel "Die wetenskapstaal in Suid-Afrika" waarin hy tot die konklusie kom dat Engels eintlik dié wetenskapstaal in Suid-Afrika is. Volgens Garbers (1990:220) het 'n wetenskapstaal in Suid-Afrika drie duidelike funksies (wat hier net kortliks genoem word):

* Dit weerspieël iets van die wetenskapsbeoefening (en beskawingsvlak) in Suid-Afrika.

* Dit verbeter of maak kommunikasie moontlik tussen wetenskaplikes onderling en tussen wetenskaplikes en ander groepe (sowel nasionaal as internasionaal).

* Dit dien as instrument vir wetenskapsbeoefening as sodanig.

Indien met inagneming van hierdie drie funksies gekyk word na Afrikaanse boeke en tydskrifartikels in Suid-Afrika, is daar volgens Garbers (1990) se getabelleerde uiteensetting van wetenskapsuitsette in die vorm van boeke en tydskrifartikels van die universiteite in Suid-Afrika vir die tydperk 1986-1988, rede tot kommer:

Tabel 3: (Garbers, 1990:228 se Tabel 2)

Wetenskapsuitsette in die vorm van boeke van die universiteite in Suid-Afrika

\begin{tabular}{|c|c|c|c|c|c|c|c|c|c|}
\hline \multirow{2}{*}{$\begin{array}{l}\text { Wetenskaps- } \\
\text { kulture }\end{array}$} & \multirow{2}{*}{$N / \%$} & \multicolumn{2}{|c|}{1986} & \multicolumn{2}{|c|}{1987} & \multicolumn{2}{|c|}{1988} & \multicolumn{2}{|c|}{ Totaal } \\
\hline & & Eng. & Afr. & Eng. & Afr. & Eng. & Afr. & Eng. & Afr. \\
\hline $\begin{array}{l}\text { Sosiale } \\
\text { Wetenskap }\end{array}$ & $\begin{array}{l}\mathrm{N} \\
\%\end{array}$ & $\begin{array}{l}64 \\
84\end{array}$ & $\begin{array}{l}12 \\
16\end{array}$ & $\begin{array}{r}104 \\
90\end{array}$ & $\begin{array}{l}12 \\
10\end{array}$ & $\begin{array}{l}94 \\
93\end{array}$ & $\begin{array}{l}7 \\
7\end{array}$ & $\begin{array}{r}262 \\
89\end{array}$ & $\begin{array}{l}31 \\
11\end{array}$ \\
\hline Humaniora & $\begin{array}{l}N \\
\%\end{array}$ & $\begin{array}{l}45 \\
74\end{array}$ & $\begin{array}{l}16 \\
26\end{array}$ & $\begin{array}{l}33 \\
56\end{array}$ & $\begin{array}{l}26 \\
44\end{array}$ & $\begin{array}{l}50 \\
63\end{array}$ & $\begin{array}{l}29 \\
37\end{array}$ & $\begin{array}{r}128 \\
64\end{array}$ & $\begin{array}{l}71 \\
36\end{array}$ \\
\hline $\begin{array}{l}\text { Natuur- } \\
\text { wetenskap }\end{array}$ & $\begin{array}{l}\mathrm{N} \\
\%\end{array}$ & $\begin{array}{r}32 \\
100\end{array}$ & $\begin{array}{l}0 \\
0\end{array}$ & $\begin{array}{r}50 \\
100\end{array}$ & $\begin{array}{l}0 \\
0\end{array}$ & $\begin{array}{r}30 \\
100\end{array}$ & $\begin{array}{l}0 \\
0\end{array}$ & $\begin{array}{l}112 \\
100\end{array}$ & $\begin{array}{l}0 \\
0\end{array}$ \\
\hline $\begin{array}{l}\text { Ingenieurs- } \\
\text { wetenskap }\end{array}$ & $\begin{array}{l}\mathrm{N} \\
\%\end{array}$ & $\begin{array}{r}13 \\
100\end{array}$ & $\begin{array}{l}0 \\
0\end{array}$ & $\begin{array}{r}31 \\
100\end{array}$ & $\begin{array}{l}0 \\
0\end{array}$ & $\begin{array}{r}12 \\
100\end{array}$ & $\begin{array}{l}0 \\
0\end{array}$ & $\begin{array}{r}56 \\
100\end{array}$ & $\begin{array}{l}0 \\
0\end{array}$ \\
\hline $\begin{array}{l}\text { Landbou- en } \\
\text { Biologiese Wetenskap }\end{array}$ & $\begin{array}{l}\mathrm{N} \\
\%\end{array}$ & $\begin{array}{r}22 \\
100\end{array}$ & $\begin{array}{l}0 \\
0\end{array}$ & $\begin{array}{r}20 \\
100\end{array}$ & $\begin{array}{l}0 \\
0\end{array}$ & $\begin{array}{l}21 \\
95\end{array}$ & $\begin{array}{l}1 \\
5\end{array}$ & $\begin{array}{l}63 \\
98\end{array}$ & $\begin{array}{l}1 \\
2\end{array}$ \\
\hline $\begin{array}{l}\text { Mediese } \\
\text { Wetenskap }\end{array}$ & $\begin{array}{l}N \\
\%\end{array}$ & $\begin{array}{l}27 \\
93\end{array}$ & $\begin{array}{l}2 \\
7\end{array}$ & $\begin{array}{r}29 \\
100\end{array}$ & $\begin{array}{l}0 \\
0\end{array}$ & $\begin{array}{r}20 \\
100\end{array}$ & $\begin{array}{l}0 \\
0\end{array}$ & $\begin{array}{l}76 \\
97\end{array}$ & $\begin{array}{l}2 \\
3\end{array}$ \\
\hline Totaal & $\mathrm{N}$ & 203 & 30 & 267 & 38 & 227 & 37 & 697 & 105 \\
\hline & $\%$ & 87 & 13 & 88 & 12 & 86 & 14 & 87 & 13 \\
\hline
\end{tabular}


Tabel 4: (Garbers, 1990:229 se Tabel 3)

Wetenskapsuitsette in die vorm van tydskrifartikels van die universiteite in Suid-Afrika

\begin{tabular}{|c|c|c|c|c|c|c|c|c|c|c|}
\hline \multirow{2}{*}{$\begin{array}{l}\text { Wetenskaps- } \\
\text { kulture }\end{array}$} & \multirow{2}{*}{$N / \%$} & \multicolumn{2}{|c|}{1986} & \multicolumn{2}{|c|}{1987} & \multicolumn{2}{|c|}{1988} & \multicolumn{2}{|c|}{ Totaal } & \\
\hline & & Eng. & Afr. & Eng. & Afr. & Eng. & Afr. & Eng. & Afr. & \\
\hline $\begin{array}{l}\text { Sosiale } \\
\text { Wetenskap }\end{array}$ & $\begin{array}{l}\mathrm{N} \\
0_{0}\end{array}$ & $\begin{array}{r}599 \\
92\end{array}$ & $\begin{array}{r}54 \\
8\end{array}$ & $\begin{array}{r}831 \\
80\end{array}$ & $\begin{array}{r}211 \\
20\end{array}$ & $\begin{array}{r}788 \\
89\end{array}$ & $\begin{array}{r}101 \\
11\end{array}$ & $\begin{array}{r}2218 \\
86\end{array}$ & $\begin{array}{r}366 \\
14\end{array}$ & \\
\hline Humaniora & $\begin{array}{l}\mathrm{N} \\
\%\end{array}$ & $\begin{array}{r}155 \\
61\end{array}$ & $\begin{array}{l}70 \\
40\end{array}$ & $\begin{array}{r}286 \\
78\end{array}$ & $\begin{array}{l}58 \\
22\end{array}$ & $\begin{array}{r}304 \\
71\end{array}$ & $\begin{array}{r}125 \\
29\end{array}$ & $\begin{array}{r}745 \\
75\end{array}$ & $\begin{array}{r}253 \\
25\end{array}$ & \\
\hline $\begin{array}{l}\text { Natuur- } \\
\text { wetenskap }\end{array}$ & $\begin{array}{l}\mathrm{N} \\
\%\end{array}$ & $\begin{array}{r}693 \\
97\end{array}$ & $\begin{array}{r}23 \\
3\end{array}$ & $\begin{array}{r}922 \\
98\end{array}$ & $\begin{array}{r}17 \\
2\end{array}$ & $\begin{array}{r}748 \\
99\end{array}$ & $\begin{array}{r}11 \\
1\end{array}$ & $\begin{array}{r}2363 \\
98\end{array}$ & $\begin{array}{r}51 \\
2\end{array}$ & \\
\hline $\begin{array}{l}\text { Ingenieurs- } \\
\text { wetenskap }\end{array}$ & $\begin{array}{l}\mathrm{N} \\
\%\end{array}$ & $\begin{array}{r}46 \\
100\end{array}$ & $\begin{array}{l}0 \\
0\end{array}$ & $\begin{array}{l}86 \\
99\end{array}$ & $\begin{array}{l}1 \\
1\end{array}$ & $\begin{array}{r}107 \\
99\end{array}$ & $\begin{array}{l}1 \\
1\end{array}$ & $\begin{array}{r}239 \\
99\end{array}$ & $\begin{array}{l}2 \\
1\end{array}$ & \\
\hline \begin{tabular}{|l|} 
Landbou- en \\
Biologiese Wetenskap
\end{tabular} & $\begin{array}{l}\mathrm{N} \\
\%\end{array}$ & $\begin{array}{l}508 \\
100\end{array}$ & $\begin{array}{l}0 \\
0\end{array}$ & $\begin{array}{r}628 \\
96\end{array}$ & $\begin{array}{r}24 \\
4\end{array}$ & $\begin{array}{r}602 \\
98\end{array}$ & $\begin{array}{r}14 \\
2 \\
\end{array}$ & $\begin{array}{r}1738 \\
98\end{array}$ & $\begin{array}{r}38 \\
2\end{array}$ & \\
\hline $\begin{array}{l}\text { Mediese } \\
\text { Wetenskap }\end{array}$ & $\begin{array}{l}N \\
\%\end{array}$ & $\begin{array}{r}1505 \\
100\end{array}$ & $\begin{array}{l}0 \\
0\end{array}$ & $\begin{array}{r}1242 \\
100\end{array}$ & $\begin{array}{l}0 \\
0\end{array}$ & $\begin{array}{r}1287 \\
99\end{array}$ & $\begin{array}{r}12 \\
1\end{array}$ & $\begin{array}{r}4034 \\
100\end{array}$ & $\begin{array}{r}12 \\
0\end{array}$ & \\
\hline Totaal & $\begin{array}{l}N \\
\%\end{array}$ & $\begin{array}{r}3506 \\
96\end{array}$ & $\begin{array}{r}147 \\
4\end{array}$ & $\begin{array}{r}3995 \\
93\end{array}$ & $\begin{array}{r}311 \\
7\end{array}$ & $\begin{array}{r}3836 \\
94\end{array}$ & $\begin{array}{r}264 \\
6\end{array}$ & $\begin{array}{r}11337 \\
94\end{array}$ & $\begin{array}{r}722 \\
6\end{array}$ & $\begin{array}{r}12059 \\
100\end{array}$ \\
\hline
\end{tabular}

Hieruit blyk onder meer die volgende feite ten opsigte van Afrikaans:

- Tahel 3: Net 13\% van al die boeke wat oor die jare 1986-1988 gepubliseer is, was in Afrikaans, en die res (87\%) in Engels. Slegs in die geestes- en sosiale wetenskappe was daar noemenswaardige tekens van 'n gewilligheid om in Afrikaans te publiseer: by die geesteswetenskappe was $36 \%$ van die gepubliseerde boeke in Afrikaans en $64 \%$ daarvan in Engels; by die sosiale wetenskappe was die syfers $11 \%$ in Afrikaans en $89 \%$ in Engels. By die ander dissiplines is daar skaars iets om te noem.

- Tabel 4: Oorheersend is hier ook in Engels gepubliseer (94\%). Weer eens lê die oorwig vir die publikasie van tydskrifartikels in Afrikaans by die geestes- en sosiale wetenskappe: $86 \%$ van die tydskrifartikels in Afrikaans vir die jare 1986-1988 is gepubliseer deur geesteswetenskaplikes. Garbers (1990:231) sê dit is klaarblyklik "... 'n aanduiding van die groter kultuurgebondenheid van die geesteswetenskappe en waarskynlik 'n mindere gerigtheid op die internasionale wetenskapsterrein by geesteswetenskaplikes".

\subsection{Perspektiewe ten opsigte van wetenskapstaal}

Uit die gegewens en argumente in $3.1-3.3 \mathrm{kom}$ die volgende gesigspunte na vore: (Vergelyk hier veral Garbers, 1990:243-245.) 
* Engels het naamlik ook in Suid-Afrika grootliks dié wetenskapstaal geword waarin wetenskaplikes hulle bydraes lewer. Aan die een kant is dit natuurlik positief: deur Engels as universele wetenskapstaal te aanvaar, sal die RSA in die toekoms nie noodwendig op wetenskaplike inligtingsgebied agter raak nie - dit is ' $n$ argument waarvoor ' $n$ mens nie werklik jou (emosionele) oë kan sluit nie.

* $\quad$ "Die ontwikkeling van ('n) wetenskapstaal is een van die getrouste barometers van die beskawingsvlak van 'n land" (Garbers, 1990:243). Engels word wel as bate aanvaar om baie goeie redes, maar Afrikaans kan insgelyks ook om baie ander goeie redes as wetenskapstaal in Suider-Afrika nie afgeskeep word nie:

- Afrikaans het alreeds die status van 'n amptelike taal bereik en het homself oor die afgelope 50 jaar plus bewys as ' $n$ taal wat in terme van die uitoefening van sy hoëtaalfunksies wel gebruik kan word vir die uitdruk van die wetenskap.

- Afrikaans is by uitstek geskik om op grond van sy aard en status as taal van Afrika uniek uitdrukking te gee aan ervarings van Afrika. Daar is byvoorbeeld talle Afrikaanse leenwoorde in Engels opgeneem wat Afrikaans se betrokkenheid by die bodem en kultuur van Afrika weerspieël (bv. koppie, veld, kraal, ens.)

- $\quad$ Talle organisasies (bv. die S.A. Akademie vir Wetenskap en Kuns) stel hulle ten doel om Afrikaans as wetenskapstaal na sy volle potensiaal te help ontwikkel.

\subsection{Die bevordering van Afrikaans se taalstatus}

Afrikaanse wetenskaplikes kan daartoe meehelp om Afrikaans se status as 'n wetenskapstaal te laat toeneem deur onder meer die volgende stappe te doen:

* Meer handboeke kan in Afrikaans gepubliseer word. As dit daarop neerkom, kan desnoods eie handboeke geskryf word, want die ingevoerde Engelse (meestal Amerikaanse) handboeke pas nie noodwendig aan by die eiesoortige behoeftes van die Afrikaanse student(e) nie.

* Op universiteitskampusse kan Afrikaanssprekende wetenskaplikes hulle vakdissiplines doseer in die taal wat vir hulle die natuurlikste kom, naamlik Afrikaans.

* Moedig verhandelinge en proefskrifte in Afrikaans aan en weerstaan die druk om hierdie soort navorsing eerder in Engels af te handel ter wille van 
'internasionale' aanvaarding - as die betrokke stuk navorsing dan werklik so goed is, kan dit sekerlik vertaal word vir wyer erkenning.

* Skep eie Afrikaanse vakterminologie. Sodoende kan gehelp word om 'n Afrikaanse tradisie tot stand te laat bring.

(Vergelyk Steyn, 1980:420-426, Van der Elst, 1991.)

\subsection{Samevattend}

Kennis van Afrikaans is wel nuttig in die beoefening van die wetenskap in SuidAfrika, maar die Afrikaanssprekende se gewilligheid tot ondergrawing van sy eie taal en kultuur, kan op die lange duur beslis die gebruik van Afrikaans as wetenskapstaal belemmer. Die vraag is: moet Afrikaanssprekende wetenskaplikes (in alle dissiplines!) nie meer moeite begin doen om ook die resultate van hulle navorsing in Afrikaans beskikbaar te stel nie?

\section{Afrikaans as vakdissipline en sy waarde vir die beoefening van ander vakdissiplines}

\subsection{Die inhoud van die vak Afrikaans}

Universiteitskursusse in die Departemente Afrikaans/Afrikaans en Nederlands by die meerderheid universiteite in Suid-Afrika stem in 'n groot mate ooreen ten opsigte van die inhoude van die betrokke kursusse. Daar mag hier en daar wel 'n afwyking voorkom in terme van byvoorbeeld die ordening van die onderafdelings van die onderskeie kursusse, maar in bree trekke sal 'n tipiese driejarige graadkursus in die vak (-dissipline) Afrikaans/Afrikaans en Nederlands in die loop van die drie voorgraadse jare die volgende komponente (in wisselende intensiteite en dosisse) insluit:

* Letterkunde:

Afrikaanse prosa Nederlandse prosa

Afrikaanse poësie Nederlandse poësie

Afrikaanse drama Nederlandse drama 
Afrikaanse sintaksis

Afrikaanse semantiek

Afrikaanse morfologie

Afrikaanse fonetiek en fonologie

Sosiolinguistiek/Taalvariasie

Taalgebruikskunde/Taalvaardigheid

Taalgeskiedenis/Historiese taalkunde

Basiese Nederlandse grammatika (soms).

Dis moeilik om nagraadse kursusse by so 'n oorsigtelike beskrywing te betrek, want die aanbied en inhoude van Honneurs- en (by sommige universiteite) gedoseerde M.A.-kursusse berus in 'n baie groot mate op die besondere kundigheid van die betrokke dosente in die bepaalde departement. Dis in elk geval meestal ' $n$ verdere uitbreiding op reeds gegewe voorgraadse inhoude of 'n toevoeging van nuwe kursusopsies (soos taalpolitiek, taalbeplanning, stilistiek, tekslinguistiek, vertaalkunde, literêre teorieë, en so meer ).

\subsection{Die begrip interdissiplinêr}

Die vraag is nou: hoe kan hierdie inhoude vir ander dissiplines iets beteken? 'n Goeie vertrekpunt, voordat 'n antwoord op so 'n vraag gegee kan word, is om eerstens vas te stel wat presies bedoel word met die begrip interdissiplinêr. Volgens die WAT (Deel II, 1974:205) is 'n "dissipline" "... enige onderdeel van ' $n$ wetenskap wat deur 'n eie onderwerp begrens word: Die dissiplines van die filosofiese wetenskap, soos die logika, etiek en sielkunde". Die Nasionale Woordeboek (1987:105) omskryf dit weer soos volg: "vertakking van die wetenskap met eie navorsingsterrein en -metodes". Daarenteen word "inter-" verklaar as "tussen; tussen die dele van; onderling, wederkerig" (Nasionale Woordeboek 1987:224).

Interdissiplinêr sou volgens hierdie omskrywings ruweg verklaar kan word as die 'wisselwerking tussen wetenskappe met eiesoortige navorsingsterreine en -metodes' - die implikasie is dan dat die betrokke wetenskapsterreine by mekaar kan baat in terme van inhoude en metodes. Swanepoel (1991:35) is meer eksplisiet hieroor in sy artikel "Interdissiplinêre taal- en literatuurstudie in SuidAfrika" as hy naamlik sê: : ".. interdisciplinary work does require a sharing of common experiences and a greater interaction between departments". Dis duidelik dat die deel van "common experiences" en selfs die "interaksie tussen departemente' tot wedersyde voordeel kan strek. Dié aspekte word vervolgens verder bespreek. 


\subsection{Die waarde van Afrikaans vir interdissiplinêre doeleindes}

$\mathrm{Na}$ aanleiding van wat in 4.2 gesê is, kan die vraag opnuut gevra word: hoe kan die inhoude en metodes van die vak Afrikaans/Afrikaans en Nederlands ander dissiplines tot voordeel strek? Hierop is nie daar nie altyd 'n presiese antwoord te gee nie, want die sienings en ervarings van mense sal 'n rol speel om die omvang van die invloed/wisselwerking te bepaal. Hier onder word nietemin kortliks gewys op enkele van die ander dissiplines wat kan voordeel trek uit hulle interdissiplinêre kontak met die $v a k$ Afrikaans/Afrikaans en Nederlands:

* Taal- en Literatuurwetenskap:

Swanepoel (1991) voer in sy oorsigtelike artikel aan dat die gebiede van die taal- en literatuurwetenskap reeds heelwat voorbeelde van suksesvolle interdissiplinêre kontak opgelewer het. Ten opsigte van samewerking op taalwetenskapvlak is daar onder meer die bundel Norme vir taalgebruik in die Spil Plus-reeks (Nr. 10, Dept. Algemene Taalwetenskap, Universiteit van Stellenbosch), waaraan taalkundiges vanuit 'n verskeidenheid dissiplines (o.a. Algemene Taalwetenskap/Linguistiek, Afrikaans/Afrikaans en Nederlands, Duits, Engels, Afrikatale, Sosiologie) meegewerk het. Insgelyks is die tydskrif van die Linguistevereniging van Suider-Afrika, naamlik die S.A. Tydskrif vir Taalkunde S.A. Journal for Linguistics 'n bron waarin artikels van taalkundiges/taalwetenskaplikes vanuit die onderskeie dissiplines van Algemene Taalwetenskap/Linguistiek, Afrikaans/Afrikaans en Nederlands, Engels, Afrikatale, Semitistiek verskyn. Ook in die Tydskrif vir Taalonderrig, die tydskrif van die S.A. Vereniging vir Taalonderrig, kom gereeld artikels voor vanuit dissiplines soos die Opvoedkunde, Afrikaans/Afrikaans en Nederlands, Engels, Linguistiek, en so meer. Swanepoel (1991:37-40) wys ook op interdissiplinêre samewerking tussen dissiplines met die LEXINETprogram, die STANON-projek (waar navorsing oor standaard- en niestandaardvariëteite binne die Suider-Afrikaanse verband - Afrikatale, Engels, Afrikaans - binne een projek gekoördineer word). Die verskyning van The Language Atlas of South Africa: Language and Literacy Patterns (1990) onder beskerming van die $\mathrm{RGN}$, is ook 'n goeie resultaat van suksesvolle interdissiplinêre samewerking.

Ook op literatuurvlak is daar goeie voorbeelde van sodanige interdissiplinêre samewerking. Die S.A. Vereniging vir Literatuurwetenskap (SAVAL) en sy Tydskrif vir Literatuurwetenskap, die Afrikaanse Letterkundevereniging (ALV) en sy tydskif Stilet, die vroeëre SENSAL (Sentrum vir S.A. Letterkunde-navorsing) van die RGN, die S.A. LITERATUUR-projek, die tydskrifte Literator en die Tydskrif vir Letterkunde wat nie skroom om inter- 
dissiplinêre artikels te plaas nie, en ander projekte en publikasies is sprekend van die sukses wat al met interdissiplinêre skakeling behaal is.

Waar en hoe speel die inhoud en metodes van die vak Afrikaans/Afrikaans en Nederlands hier ' $n$ rol? Die insig en interpretasies van kundiges in hierdie vak, op sowel taal- as letterkundige vlak, help om die teoretisering van die vak Taal- en Literatuurwetenskap/Algemene Taalwetenskap/Linguistiek/ Literatuurwetenskap praktyk te maak. Enkele voorbeelde hiervan: die aanleer van 'n Afrikaanse fonetiese alfabet (en gevolglik die onderskeiding van Afrikaanse data) kan help om 'n verskynsel soos assimilasie waaroor heelwat geteoretiseer kan word, beter toe te lig; kennis van die Afrikaanse letterkunde skep 'n maklik beskikbare toepassingsveld om met die literêre teorieë van die literatuurwetenskap te eksperimenteer.

Swanepoel (1991:41) meen dat groter onderlinge (lees: interdissiplinêre) samewerking kan bydra om groter/beter "... interaksie tussen die taal- en literatuurverskynsels van volke/mense en kulture" tot stand te bring. Dit kan bereik word deur met behulp van samewerkingsprogramme tussen departemente en navorsingsinstansies meer nasionaal-gerigte projekte aan te pak deur ôf saam te werk aan nuwe of bestaande projekte óf deur beter onderlinge skakeling nuwe projekte te identifiseer en dit dan gesamentlik aan te pak. So kan dit byvoorbeeld tot ' $n$ beter benutting van finansiële bronne lei as die opleiding vir vergelykende studie gekoôrdineerd aangepak kan word. ${ }^{6}$

* Opvoedkunde:

Die bewusmaking van sosiale onderskeide en daarmee saam taalonderskeide tussen mense en groepe, is van groot waarde vir effektiewe onderrig op skool. (Die opstellers van die nuwe konsepleerplan vir die onderrig van Afrikaans op skool het byvoorbeeld deeglik rekening gehou met hierdie aspek vergelyk die verslag van die Ad hoc-Komitee oor die Vernuwing van die Onderrig van Afrikaans van 30 Junie 1992). Die insigte wat onder meer die Afrikaanse sosiolinguistiek in hierdie verband kan meebring, kan help om groter begrip tot stand te laat kom vir die feit dat taalagterstande in 'n verskeurde Suid-Afrikaanse samelewing noodwendig die taalverwerwings-

6 Die Universiteit van Kaapstad bied al byvoorbeeld die afgelope paar jaar 'n baie suksesvolle "M.A. in Literary Studies" aan waaraan meegewerk word deur 'n verskeidenheid van uitecnlopende departemente (Afrikaans en Nederlands, Engels, Duits, Frans). Dit was ook die geval by die Universiteit van Natal, Durban waar soortgelyke interdepartementele samewerking op Honneurs- en M.A.-vlak gelei het tot die instel van gewilde interdissiplinêre kursusse en opsies. 
proses nadelig kan beïnvloed en dat dit selfs die leerling se selfbeeld en sy deelname aan die totale opvoedingsaktiwiteit kan strem. Taal en ontwikkeling loop hand aan hand en daarom kan beter taalsosiologiese kennis van die Afrikaanse taalgemeenskap ' $n$ besliste bydrae lewer tot beter onderrig.

* Spraakterapie:

'n Onontbeerlike komponent van die opleiding van spraakterapeute is die aanbied van kursusse oor die fonetiek, met ander woorde oor die onderskeiding van klanke en die wyses waarop hierdie klanke in die mond gevorm word. Kennis van die Afrikaanse fonetiese alfabet en van die artikulasie van Afrikaanse klanke kan daarom die spraakterapeut help om sy werk na behore te doen.

* Kommunikasiekunde:

Die aanleer van kommunikasievaardighede en -tegnieke kan nooit los van taalvaardigheidstegnieke geskied nie. Al beskik jy oor al die teoretiese kennis van kommunikasie as vakgebied, maar jy kan dit nie praktyk maak met behulp van die een of ander taal nie, help jou kennis jou nie veel nie. Daarom sal binne 'n Afrikaanse kommunikasieopset kennis van die taalvaardigheidsaspekte van Afrikaans 'n uiters belangrike komponent van die totale opleiding vorm.

* Teologie:

Kennis van die Afrikaanse semantiek en sintaksis kan die teologie van nut wees in soverre dit kan bydra om tekseksegese te vergemaklik. Selfs kennis van die Afrikaanse letterkunde en die verskillende genres wat hier ter sake is, kan bydra tot beter begrip van besondere Bybelgedeeltes.

* Regswetenskappe:

Kennis van die effektiewe gebruik van die woord - onder meer tegnieke om die betekenisnuanses van woorde in die onderskeie woordeboeke te ontsluit, die formulering van goeie sinne in Afrikaans, bekendstelling met die natuurlike verskeidenheid in die variëteite van Afrikaans, bied vir die opleiding van regslui geweldige moontlikhede. Spesifiek vir Afrikaanse regslui wat wetgewing na behore moet analiseer en interpreteer, wat owerheidsdokumentasie moet kan beoordeel, kan kennis van die komponente van die Afrikaanse grammatika en die vaardighede wat daarmee saamgaan - soos hier bo genoem is - van besondere praktiese en professionele waarde wees. Talle hofuitsprake is al (en word steeds daagliks) in Afrikaans gemaak en volgens die presedentspraktyk in die S.A. regstelsel word telkens daaruit aangehaal alreeds dit vereis 'n behoorlike kennis van Afrikaans. 
Dié lys sou waarskynlik heelwat uitgebrei en selfs verder toegelig kan word, maar die punte wat hier aangedui is, behoort te dien as illustrasie van die feit dat Afrikaans as vak, as dissipline, ook vir ander dissiplines van waarde kan wees.

\section{Samevatting}

Daar is probeer om in hierdie artikel 'n perspektief te gee op die interdissiplinêre waarde van Afrikaans in 'n toekomstige nuwe Suid-Afrika. As Afrikaans daarin slaag om sy hoëfunksiestatus te behou, is daar baie moontlikhede vir sy verdere groei en gebruik as wetenskapstaal in Suid-Afrika. Op grond van sy vakinhoud kan Afrikaans ook verder uitgebou word as dissipline wat kan bydra om sommige van die probleme (opvoedkundig, e.a.) wat vorentoe in die die land mag opduik, beter te hanteer.

\section{Literatuurlys}

Ad hoc-Komitee vir die Vernuwing van die Onderrig van Afrikaans 1992. Nuwsbrief Vier. Kaapstad : Kaaplandse Onderwysdepartement.

Ad hoc-Komitee vir die Vernuwing van die Onderrig van Afrikaans 1992. Finale verslag oor die Onderrig van Afrikaans. 30 Junie 1992.

ATKV (in samewerking met RGN) 1991. 13.3 miljoen redes om Afrikaans te praat. Pamflet versprei in publikasies van Nasionale Pers

Carstens, W.A.M. \& Waher, H. (reds.) 1990. Standaard, alternatief of geen? - Radiogesprekke oor Afrikaans in die toekoms. LVSA-Byblad, 9(1): 1-61, Maart 1991.

Carstens, W.A.M. (red.) 1993. Radiogesprekke oor die stand van die gesprek oor Afrikaans. LVSA-Nusblad. Februarie

Combrink, J.G.H. 1991. Die toekomstige status en funksies van Afrikaans. Tydskrif vir Geesteswetenskappe, 31(2):101-112.

Combrink, J.G.H. 1992. Afrikaans en ander tale in 'n nuwe staatkundige bedeling in SuidAfrika. Referaat gelewer by die Jaarvergadering van die S.A. Akademie vir Wetenskap en Kuns te Potchefstroom, 17 Junie 1992. Gepubliseer onder dieselfde titel in die Tydskrif vir Geesteswetenskappe, 32(4):265-276. Desember.

De Villiers, M. e.a. 1987. Nasionale Woordeboek. Kaapstad : Nasou.

Du Plessis, H \& Du Plessis, L.T. (reds.) 1987. Afrikaans en taalpolitiek: 15 opstelle.

Pretoria : HAUM-Opvoedkundige Uitgewery.

Du Plessis, H. 1992. En nou, Afrikaans? Pretoria : J.L. van Schaik.

Garbers, J.G. 1990. Die wetenskapstaal in Suid-Afrika. Tydskrıf vir Geesteswetenskappe, 30(3):220-246, September.

Grobler, E., Prinsloo, K.P. \& Van der Merwe, I.J. 1990. The Language Atlas of South Africa: language and Literacy Patterns. Pretoria : HSRC.

Licca 1991. Language Planning for a Post-Apartheid South Africa. Information Booklet. Conference 5-7 April 1991. University of Pretoria.

Odendal, F.F. 1992. Standaardafrikaans en Statusafrikaans. Aambeeld, 20(1):18-23. Junie

Prinsloo, K.P. \& Van Rensburg, M.C.J. (reds.) 1984. Afrikaans: stand, taak, toekoms. Pretoria : HAUM-Opvoedkundige Uitgewery. 
Prinsloo, K.P. \& Malan, C. 1988. Kulture in kontak: die taalterrein en die kunste in SuidAfrika. In: Marais, H.C. (red.) Suid-Afrika: Perspektiewe op die toekoms. Hillcrest Owen Burgess. pp. 279-305.

Prinsloo, K.P. 1985. A Proposed Agenda for Language Planning in South Africa. In: Prinsloo, K.P. (ed.) language Planning for South Africa. S.A. Journal for Linguistics. Occasional Papers, 2:24-31, July.

Schoonees, P.C. (hoofred.) 1974. Woordeboek van die Afrikaanse Taal, Deel II (D-F). Pretoria : Staatsdrukker.

Steyn, J.C. 1980. Tuiste in eie taal. Die behoud en bestaan van Afrikaans. Kaapstad Tafelberg.

Swanepoel, C.F. 1991. Interdissiplinêre taal- en literatuurstudie in Suid-Afrika. Literator, 12(2):35-48, Augustus.

Van der Elst, J. 1991. Die PU vir CHO as Afrikaanse universiteit. Lesing gelewer by toeligtingsessie vir Bestuur van die Universiteit.

Van Rensburg, M.C.J. 1989. Oor die depolitisering van Afrikaans: vertrekpunte vir 'n gesprek. Tydskrif vir letterkunde, XXVII(2):42-47. Mei

Potchefstroomse Universiteit vir CHO 
